\title{
Bioenergy II: Scale-Up of the Milena Biomass Gasification Process
}

\author{
Christiaan M. van der Meijden \\ Hubert J. Veringa \\ Berend J. Vreugdenhil \\ Bram van der Drift
}




\title{
INTERNATIONAL JOURNAL OF CHEMICAL REACTOR ENGINEERING
}

Volume 7

Article A53

\section{Bioenergy II: Scale-Up of the Milena Biomass Gasification Process}

\author{
Christiaan M. van der Meijden* \\ Hubert J. Veringa ${ }^{\dagger}$ \\ Berend J. Vreugdenhil ${ }^{\ddagger}$ \\ Bram van der Drift ${ }^{* *}$
}

*Energy research Centre of the Netherlands, vandermeijden@ecn.nl

${ }^{\dagger}$ Eindhoven University of Technology, h.j.veringa@tue.nl

${ }^{\ddagger}$ Energy research Centre of the Netherlands, vreugdenhil@ecn.nl

**Energy research Centre of the Netherlands, vanderdrift@ecn.nl ISSN 1542-6580

Copyright (c) 2009 The Berkeley Electronic Press. All rights reserved. 


\title{
Bioenergy II: Scale-Up of the Milena Biomass Gasification Process
}

\author{
Christiaan M. van der Meijden, Hubert J. Veringa, Berend J. Vreugdenhil, and \\ Bram van der Drift
}

\begin{abstract}
The production of Substitute Natural Gas from biomass (Bio-SNG) is an attractive option to reduce $\mathrm{CO}_{2}$ emissions and replace declining fossil natural gas reserves. The Energy research Center of the Netherlands (ECN) is working on the development of a technology to convert a wide range of biomass into Bio-SNG.

The ECN Bio-SNG technology is based on indirect gasification of biomass. The MILENA indirect gasifier is developed to produce a gas, which can be upgraded into SNG with a high efficiency. Because of the indirect heating of the gasification process, no air separation is required. Char and tar are removed from the producer gas and are used as fuel to produce the required heat for the gasification process. The OLGA tar removal technology is used to remove tar and dust from the gas. After gas cleaning, the gas is catalytically converted into a mixture of $\mathrm{CH}_{4}, \mathrm{CO}_{2}$ and $\mathrm{H}_{2} \mathrm{O}$. After compression and removal of $\mathrm{CO}_{2}$ and $\mathrm{H}_{2} \mathrm{O}$, the remaining methane can be used as Bio-SNG.

ECN produced the first Bio-SNG in 2004, using a conventional fluidized bed gasifier. The lab-scale MILENA gasifier was built in 2004. The installation is capable of producing approximately $8 \mathrm{Nm}^{3} / \mathrm{h}$ methane-rich medium calorific gas with high efficiency. The lab-scale installation has been in operation for more than 1000 hours now and is working fine. Several biomass fuels were tested. Woody biomass appears to be the most suited fuel. The lab-scale gasifier is coupled to lab-scale gas cleaning installations (including OLGA) and a methanation unit. The integrated system was tested during several duration tests.

The $30 \mathrm{~kW}$ th lab-scale gasifier was scaled up to $800 \mathrm{~kW}$ th biomass input. ECN has recently finished the construction of this pilot-scale gasifier, which has been taken into operation in the summer of 2008. First results, using wood as a fuel, show that the gas composition is similar to gas from the lab-scale installation.
\end{abstract}


The pilot scale gasifier will be coupled to the existing pilot scale OLGA gas cleaning unit in 2009. Tests with the pilot-scale MILENA and OLGA will form the basis of a 10 MW MILENA - OLGA - gas engine demonstration plant. This demonstration will be taken into operation in 2012 and will be followed by a large SNG demonstration. $10 \mathrm{MW}$ biomass input is seen as an attractive commercial scale for combined heat and power production from biomass. The scale foreseen for a commercial single-train Bio-SNG production facility is between 50 and 500 MWth. The expected net overall efficiency from wood to Bio-SNG is $70 \%$.

KEYWORDS: allothermal conversion, biomass conversion, bio-syngas, gasification, methane, bio-cng, SNG, bio-sng, fluidized bed 


\section{Introduction}

Natural gas is a popular fuel, because it is clean and safe. The market for natural gas is increasing. Natural gas is used for local heating, combined cycle plants to produce heat and electricity, as a feedstock in the chemical industry and in the transport sector to fuel Natural Gas Vehicles (NGV's). The composition of natural gas varies, but the main component is always methane. Natural gas from fossil origin can be replaced by a Substitute Natural Gas produced from biomass (BioSNG). SNG is made to mimic the composition of the gas, the heating value and the Wobbe index. Gasification is a route to convert a wide range of biomass feed stocks into Bio-SNG with a high energetic efficiency (up to 70\%). Gasification processes can use a variety of non-food crops. These include husks, (waste) wood and different energy crops.

The Energy research Centre of the Netherlands (ECN) is developing an indirectly heated (allothermal) biomass gasification process (MILENA), optimized for the production of Bio-SNG. Fluidized bed gasification technology, on which it is based, is widely used to produce gas that can be fired in gas boilers and gas engines. The gas produced in fluidized bed gasifiers is not directly suitable to replace conventional natural gas, because the raw gas contains $\mathrm{CO}, \mathrm{H}_{2}$, several hydrocarbons and pollutants like chloride, sulfur, tars and dust. Moreover, most conventional fluidized bed gasifiers produce a gas, which contains a large amount of $\mathrm{N}_{2}$. This makes this raw gas unsuitable for upgrading into Bio-SNG. For SNG production, such gasifiers have to be operated with pure $\mathrm{O}_{2}$ instead of air. Indirect or Allothermal Fluidized Bed gasifiers can operate with air and still produce a gas virtually free of $\mathrm{N}_{2}$, because the air blown combustion process is separated from the gasification process. After removal of the pollutants the remaining mixture of $\mathrm{CO}, \mathrm{CO}_{2}, \mathrm{H}_{2}, \mathrm{H}_{2} \mathrm{O}, \mathrm{CH}_{4}$ and other hydrocarbons can be catalytically converted into Bio-SNG. The work done at ECN focuses on the development of the MILENA gasification technology for large scale production of gas which can be upgraded into Bio-SNG.

The first lab-scale MILENA gasifier was built in 2004. This lab-scale installation has been in operation for more than 1000 hours and is working well. Several biomass fuels have been tested. Woody biomass appears to be the most suited fuel. The lab-scale gasifier is coupled to lab-scale gas cleaning installations and a methanation unit. The integrated system was tested several times. ECN build an $800 \mathrm{kWth}$ pilot-scale gasifier, which has been taken into operation in the summer of 2008. The design and the first results from the MILENA pilot plant are described here.

The scale foreseen for a commercial Bio-SNG production facility is between 50 and $500 \mathrm{MW}_{\text {th }}$ or between 3 and 30 ton/h of Bio-SNG. The expected

overall efficiency from biomass to SNG is approximately $70 \%$ on $\mathrm{HHV}$ basis. 
The next step in the development of the MILENA gasification technology will be a 10 MW Bio-CHP demonstration.

\section{Production of Bio-SNG}

The overall Bio-SNG production plant exists of the following steps:

1. Biomass pre-treatment to make the biomass suitable for feeding into the gasifier

2. A gasifier where solid biomass is converted into a producer gas

3. Gas cooling and tar removal

4. Gas cleaning where the pollutants, like sulfur and chloride are removed from the producer gas

5. Catalytic conversion of producer gas into $\mathrm{CH}_{4}, \mathrm{CO}_{2}$ and $\mathrm{H}_{2} \mathrm{O}$

6. An upgrading step where water and $\mathrm{CO}_{2}$ are removed and the gas is compressed

The integrated process is schematically shown in Figure 1.

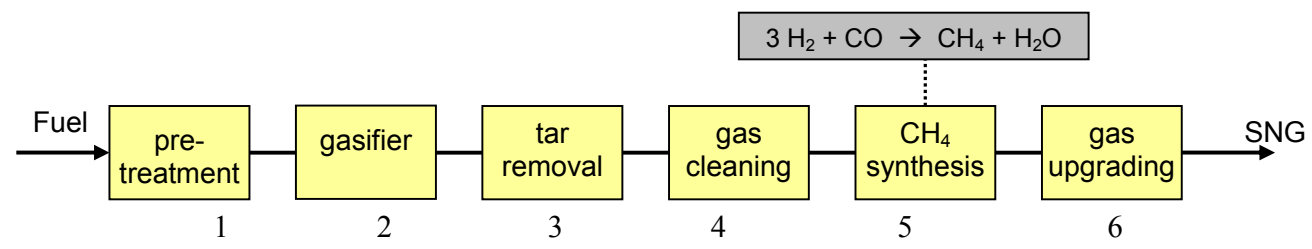

Figure 1. Overall Bio-SNG production scheme

Most raw biomass streams need some form of pre-treatment before the biomass is fed to the gasifier. In general the pre-treatment involves drying to $25 \%$ moisture or less and size reduction to chips of some centimeters.

Several biomass gasification technologies are suited for the production of gas which can be upgraded to SNG. These gasifiers can be divided in high temperature gasifiers (typically $1300^{\circ} \mathrm{C}$ ) producing a relatively clean syngas and low temperature gasifiers (typically $850^{\circ} \mathrm{C}$ ) producing a producer gas which needs intensive downstream polishing. Syngas contains only $\mathrm{CO}$ and $\mathrm{H}_{2}$ as the combustible components and producer gas contains $\mathrm{CO}, \mathrm{H}_{2}, \mathrm{CH}_{4}, \mathrm{C}_{2} \mathrm{H}_{4}$ and $\mathrm{C}_{6} \mathrm{H}_{6}$ as the main combustible components. If $\mathrm{CH}_{4}$ is the required end product, a producer gas containing a substantial amount of methane is the preferred intermediate product, as it is energy-wise more beneficial to produce $\mathrm{CH}_{4}$ out of a gas already containing $\mathrm{CH}_{4}$. Entrained flow (EF) gasifiers are typical examples of 
high temperature gasifiers. Entrained flow gasifiers are widely in use to convert coal into syngas as well as for co-gasification of biomass coal mixtures (Kanaar et al., 2006). Air blown Bubbling Fluidized Bed (BFB) and Circulating Fluidized Bed (CFB) gasifiers are built at a commercial scale, but the gas is diluted with nitrogen. An $18 \mathrm{MW}_{\text {th }}$ demonstration plant in Värnamo (Sweden) will be converted from air blown to oxygen/steam blown operation (Waldheim, 2005), this makes the gas suited for upgrading to SNG. Indirect or allothermal gasification processes do not need oxygen in the gasification part of the reactor, because the heat for the endothermic gasification is produced in a separate combustion reactor. The heat is transported from the combustor reactor to the gasification reactor by the circulating bed material (e.g. sand). A well known example of an indirect gasifier is the FICFB gasifier developed by the Vienna University of Technology (Proell et al., 2007). The MILENA technology is an indirect gasifier developed by ECN.

Gas coming from the gasifier needs to be cooled and cleaned. Producer gas from medium temperature gasifiers, like BFB's, CFB's and indirect gasifiers contain tars. Tars are heavy hydrocarbons, which can condense when the gas is cooling down. Condensed tars can block downstream equipment and will have to be removed. Removed tars can be returned to the gasifier where they contribute as fuel. ECN uses the OLGA gas cleaning technology to remove dust and tar (Boerrigter et al., 2005). The partially cleaned gas contains some residual sulfur and chloride. Several technologies are commercially available for the removal of these components. Adsorbents are a good option for removal of chloride and sulfur when the quantities are low. ECN selected adsorbents for the lab-scale installation and expects that this is also a commercially acceptable option for large scale commercial units when biomass is used with a low sulfur and chloride content like wood.

The cleaned gas can be converted into $\mathrm{CH}_{4}$ by several catalytic processes. In general a nickel catalyst is used. The conversion of the syngas or producer gas into methane is endothermic. After compression, removal of $\mathrm{H}_{2} \mathrm{O}$ and $\mathrm{CO}_{2}$, the gas is ready to be used as SNG. 


\section{MILENA gasification process}

The MILENA gasification process is an indirect or allothermal process, based on fluidized bed technology. Indirect or allothermal fluidized bed gasifiers operate mostly between 800 and $1000^{\circ} \mathrm{C}$. The operating temperature is kept below the melting temperature of the ash. In an indirect gasifier, the conversion process is done in two separate reactors. Figure 2 shows the basic principles of indirect gasification. Biomass is gasified in the first reactor. The heat required for the gasification comes from a second reactor where the char remaining from the first reactor is combusted. A circulating bed material (e.g. sand or olivine) is used to transport the heat from the combustor to the gasifier and the char from the

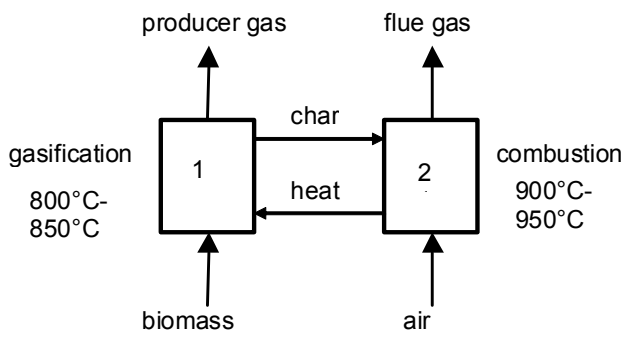

Figure 2. Schematic drawing of the indirect gasification process. gasifier to the combustor. The producer gas from reactor 1 and the flue gas from reactor 2 leave the installation in separate streams. Air is used for the combustion of char; the flue gas leaves the installation separately. The nitrogen in the flue gas therefore does not dilute the producer gas. The producer gas from the gasifier contains the same components as gas from an oxygenblown CFB gasifier, but contains less $\mathrm{CO}_{2}$, because the gas is not diluted with flue gas.

Indirect gasification concepts under development or demonstration are the Silvagas process (Paisley et al., 2002), the MILENA, and the FICFB process (Hofbauer et al., 1997). The FICFB gasifier requires a relatively large amount of steam to gasify the biomass. This results into a low tar content, but creates an efficiency loss, because the steam is heated up to process temperature. Typical steam to biomass ratios for the FICFB gasifier are in the range between 0.7 and 1.1 (Hofbauer et al., 2002) compared to approximately 0.1 for the MILENA gasifier.

The first design of the MILENA gasifier was made in 1999. The design was based on the experiences gained with constructing, modifying and operating the $500 \mathrm{kWth}$ BIKVIN CFB gasifier (van der Drift et al., 2002). The limited carbon conversion and the low heating value of the producer gas from the CFB gasifier were seen as important drawbacks and were the main drivers for developing a new gasification technology. A cold flow setup of the MILENA gasifier, for hydrodynamic testing, was built in 2000. Financing a lab-scale installation appeared to be problematic, because there was no interest in a new 
gasification technology at that time. This changed when SNG was identified as a promising bio-fuel and indirect gasification was identified as a promising technology for production of Bio-SNG (Mozaffarian et al., 2004). The construction of the $30 \mathrm{kWth}$ MILENA installation was started in 2003. The installation was taken into operation in 2004. Financing of the $800 \mathrm{kWth}$ MILENA pilot plant was approved in 2006 and the construction was finished in 2008.

The MILENA gasifier contains separate sections for gasification and combustion. Figure 3 shows a simplified scheme of the MILENA process. The gasification section consists of three parts: riser (1), settling chamber (2) and downcomer (3). The combustion section contains three parts, the bubbling fluidized bed combustor (4), the freeboard (5) and the sand transport zone (6).

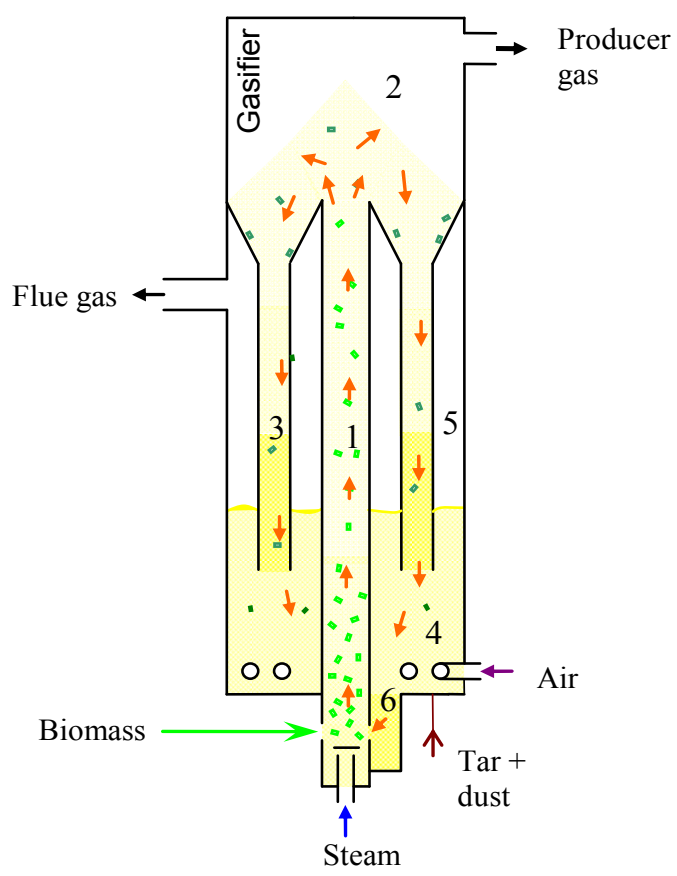

$\rightarrow$ Circulating bed material

- Biomass particle

- Char particle

Figure 3. Simplified scheme of MILENA gasifier
The arrows in Figure 3 represent the circulating bed material.

The processes in the gasification section will be explained first followed by the process in the combustion section. Biomass (e.g. wood) is fed into the riser (1). A small amount of superheated steam is added from below to create a fluidized region for the circulating bed material. Hot bed material (typically $925^{\circ} \mathrm{C}$ sand or olivine of $0.2-0.3 \mathrm{~mm}$ ) enters the riser from the combustor through a hole in the riser (opposite and just above of the biomass feeding point). The bed material heats the biomass to $850^{\circ} \mathrm{C}$. The heated biomass particles degasify; and subsequently are converted into gas, tar and char. The volume created by the gas from the biomass increases the vertical gas flow to approximately $6 \mathrm{~m} / \mathrm{s}$, and therewith creates a "turbulent fluidization" regime in the riser. The bed material is blown out of the riser together with the degassed biomass particles (char). The vertical velocity of the 
gas is reduced in the settling chamber (2), causing the larger solids (bed material and char) to separate from the gas and fall down into the downcomers (3). The producer gas leaves the reactor from the top and is sent to the cooling and gas cleaning section. Typical residence time of the gas is several seconds.

The combustor operates as a bubbling fluidized bed (BFB). The downcomer transports bed material and char from the gasification section into the combustor. Tar and dust, separated from the producer gas, are also returned to the combustor (4). Char, tar and carbon containing dust are burned with air to heat the bed material to approximately $925^{\circ} \mathrm{C}$. Secondary air is added in the freeboard (5) of the combustor to reduce $\mathrm{CO}$ and $\mathrm{C}_{\mathrm{x}} \mathrm{H}_{\mathrm{y}}$ emissions. Flue gas leaves the reactor to be cooled, de-dusted and stacked. The heated bed material leaves the bottom of the combustor, via the sand transport zone (6) through a hole into the riser. No additional heat input is required as all heat needed for the gasification process is produced by the combustion of the char and tar in the combustor. The flue gas leaving the MILENA installation is cooled down to approximately $180^{\circ} \mathrm{C}$ and is cleaned in a bag house filter. If clean wood is used as a fuel, no additional flue gas cleaning is required.

Hot producer gas from the gasifier contains several contaminants such as dust, tar, chloride and sulfur, which have to be removed before the catalytic conversion of the gas into Bio-SNG. All fluidized bed gasifiers produce gas, which contains some tar. Tar compounds condense when the gas is cooled, which makes the gas very difficult to handle, especially in combination with dust. The producer gas is cooled in a heat exchanger, designed to treat gas which contains tar and dust. The heat is used to pre-heat combustion air. Tar and dust are removed from the gas in the OLGA gas cleaning section (Boerrigter et al., 2005). The OLGA gas cleaning technology is based on scrubbing with liquid oil. Dust and tar removed from the producer gas are sent to the combustor of the MILENA gasifier. The cleaned producer gas, contains mainly $\mathrm{CO}, \mathrm{CO}_{2}, \mathrm{H}_{2}, \mathrm{CH}_{4}, \mathrm{C}_{2} \mathrm{H}_{4}$ and $\mathrm{C}_{6} \mathrm{H}_{6}$, which can be used in gas boilers, gas engines and gas turbines. After removal of chloride and sulfur the gas can be used in fuel cells or can be catalytically upgraded into SNG or syngas. Syngas can be converted into FischerTropsch diesel.

The preliminary design for the MILENA gasification technology was originally done at a scale of $10 \mathrm{MW}_{\text {th }}$. The original application foreseen for the technology was producing gas for a gas engine. $10 \mathrm{MW}_{\text {th }}$ biomass input is seen as an attractive commercial scale. De pilot scale design is a downscaling of the 10 $\mathrm{MW}_{\text {th }}$ design and the lab-scale design is a downscaling of the pilot plant. 


\section{Lab-Scale installation}

The design of the lab-scale installation was based on a preliminary design made for the pilot plant and a cold flow model. The cold flow was used to measure the bed material circulation rate for different configurations and dimensions. The original design capacity of the installation was $5 \mathrm{~kg} / \mathrm{h}$ of wood, because this was the limit for lab-scale installations at that time. Installations above this scale required elaborate safety measures, which would increase the costs. A smaller scale was seen as less realistic from hydrodynamics point of view. The installation was build as a multifunctional gasifier; the 'insert' (combination of the riser and settling chamber) is removable such that without the insert the MILENA can be used as a bubbling fluidized bed gasifier or combustor. The labscale MILENA gasifier was built in 2004.

The lab-scale installation is made of stainless steel (grade 253MA). This type of steel can withstand temperatures up to $1100^{\circ} \mathrm{C}$. Heat loss from the process is compensated for by high temperature electrical trace heating and external insulation. The riser is fluidized with steam. The amount of fluidization steam varies between 0.1 and $2 \mathrm{~kg} / \mathrm{h}$. The amount of steam required to fluidize the riser is low $(0.1 \mathrm{~kg} / \mathrm{h})$, but additional steam is used to increase the water content of the producer gas, because the biomass used for lab-scale experiments is relatively dry (10 wt.\% moisture), whereas the fuel foreseen for commercial applications contains more moisture ( $25 \mathrm{wt.} \%)$.

The lab-scale gasifier is coupled to a lab-scale gas cleaning installation and a methanation unit. The entire system operates at atmospheric pressure.

Figure 4 shows the MILENA lab-scale gasifier (left) and the OLGA tar removal system (right). The two bunkers on the left are used to feed the fuel (small wood particles) to the gasifier.
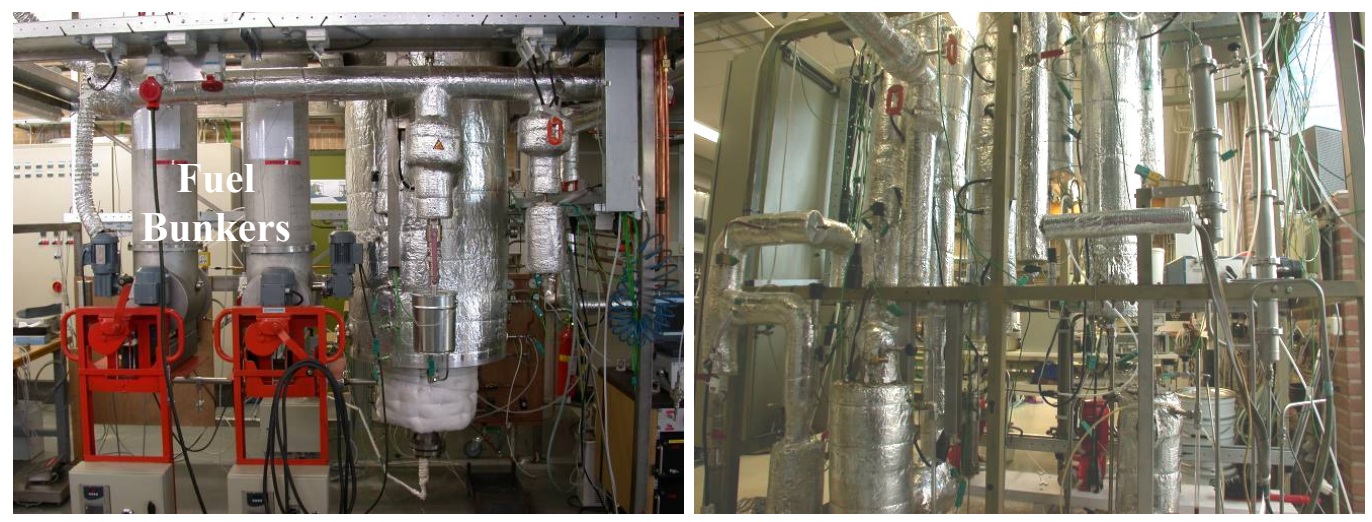

Figure 4. Photos of lab-scale MILENA (left) and OLGA (right) installation 
The MILENA lab-scale installation has been used for more than 1000 hours. The performance of the lab-scale gasifier is according expectations (van der Meijden et al., 2007). The produced gas is of medium calorific value and the nitrogen content is low (typical below 5\%). The fuel conversion is complete. The ashes that leave the combustor are grey / white, which means that the carbon loss is low $(<<1 \mathrm{wt} . \%)$. The gas from the gasifier contains tar, but the connected OLGA tar removal system is able to clean the gas.

The promising results from the MILENA lab-scale installation have led to the realization of a pilot plant.

\section{Pilot plant}

The MILENA pilot plant replaced the $500 \mathrm{kWth}$ CFB gasifier BIVKIN. The BIVKIN gasifier was connected to a producer gas cooler, OLGA tar removal system, wet scrubbers for $\mathrm{NH}_{3}, \mathrm{HCl}$ and water removal, a gas engine and a boiler. The gas engine is removed, as no additional tests are envisaged. A long duration test in 2006 proved that OLGA was able to reduce the tar content to operate a gas engine without problems (Verhoeff et al., 2007).
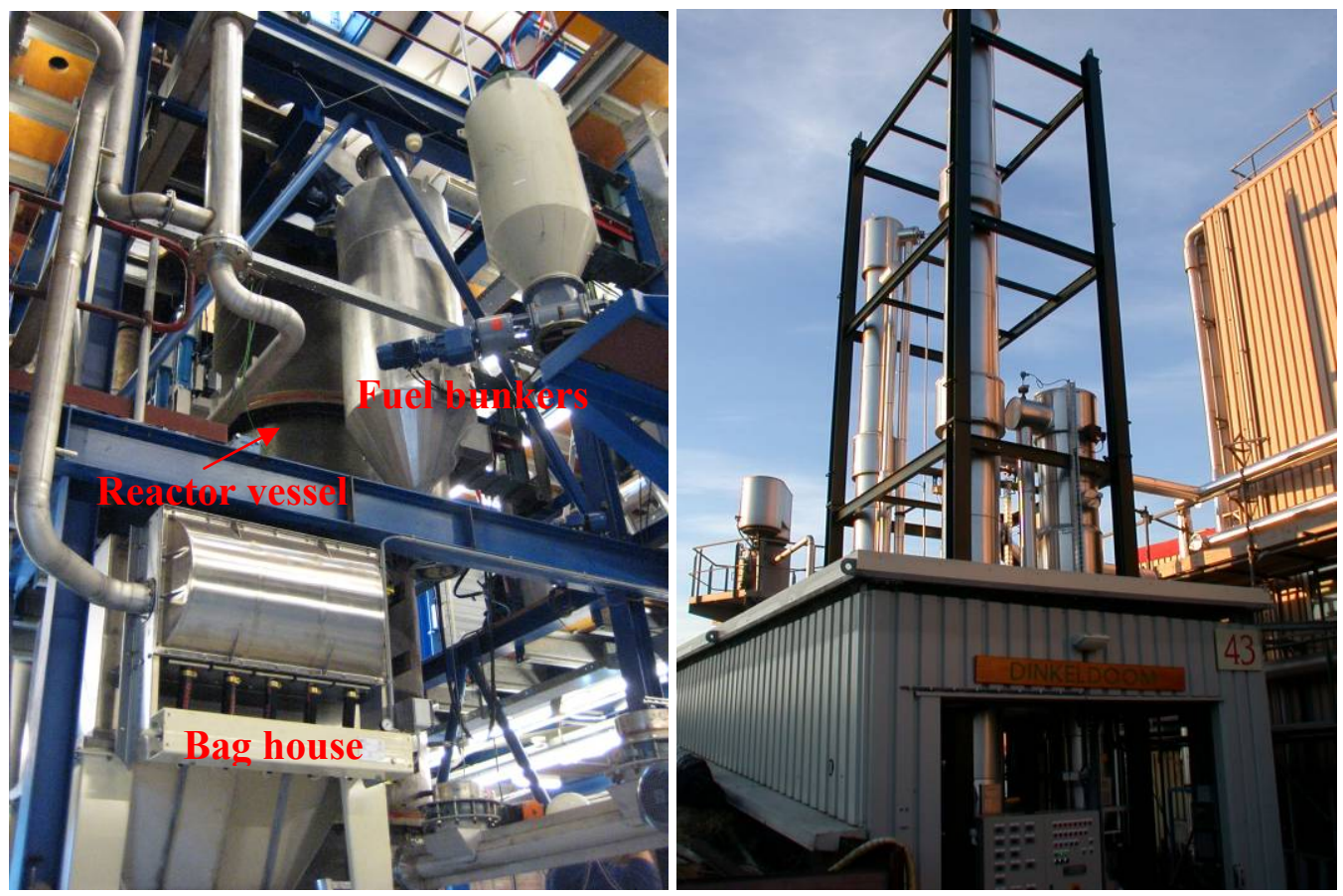

Figure 5. Photos of pilot scale MILENA (left) and OLGA (right) 
Figure 5 shows the MILENA pilot plant and the OLGA gas cleaning system. The gas cleaning system and the producer gas cooler are dimensioned on volume flow basis. The volume of gas coming from the BIVKIN gasifier was 190 $\mathrm{Nm}^{3} / \mathrm{h}$. Because the producer gas cooler and the gas cleaning system had to be used for the MILENA gasifier as well, the volume flow of producer gas coming from the MILENA had to be similar to the volume flow coming from the BIKVIN gasifier. The design volume flow for the MILENA was chosen to be $10 \%$ lower than the volume flow from the BIVKIN gasifier, to reduce the required biomass input and heat output from the boiler. Because of the increase in heating value of the gas coming from the MILENA gasifier compared to the BIVKIN gasifier the thermal input of biomass to the gasifier increased from $500 \mathrm{~kW}$ th to $800 \mathrm{kWth}$.

Table 1 shows the basic design data for the MILENA lab-scale and pilot plant. The number of downcomers in the installations was increased from a single pipe to two pipes. This improves the distribution of the char in the fluidized bed. The installation is operated at a slight overpressure to prevent air mixing with the producer gas in case of a leakage. The overpressure is kept low to minimize gas leakages around the biomass feeding system.

Table 1. Basic design data MILENA lab-scale \& pilot plant

\begin{tabular}{llcc}
\hline & & Lab-scale & Pilot plant \\
\hline Thermal input (HHV basis) & {$[\mathrm{kW}]$} & 30 & 800 \\
Biomass mass flow & {$[\mathrm{kg} / \mathrm{h}]$} & $5-6$ & 160 \\
Steam to gasifier & {$[\mathrm{kg} / \mathrm{h}]$} & $0.1-2$ & 19 \\
Riser diameter & {$[\mathrm{m}]$} & 0.036 & 0.2 \\
Combustor diameter & {$[\mathrm{m}]$} & 0.25 & 0.8 \\
Overall reactor height & {$[\mathrm{m}]$} & 2 & 8 \\
Number of downcomers & {$[-]$} & 1 & 2 \\
Combustor temperature & {$\left[{ }^{\circ} \mathrm{C}\right]$} & 925 & 925 \\
Operating pressure & {$[\mathrm{bara}]$} & 1.1 & 1.1 \\
Heat loss & {$[\mathrm{kW}]$} & 0 & $\sim 30$ \\
Estimated circulation rate bed material & {$[\mathrm{kg} / \mathrm{h}]$} & 150 & 6300 \\
Producer gas volume flow wet & {$\left[\mathrm{Nm} / \mathrm{h}^{3}\right]$} & 6 & 174 \\
Gas yield (dry gas/dry biomass) & {$\left[\mathrm{Nm}{ }^{3} / \mathrm{kg}^{1}\right.$} & 0.8 & 0.9 \\
Tar and BTX to combustor & {$[\mathrm{kW}]$} & $0^{2}$ & 55 \\
HHV gas wet basis excl. tar & {$\left[\mathrm{MJ} / \mathrm{Nm}^{3}\right]$} & 13 & 13 \\
HHV gas dry basis excl. tar & {$\left[\mathrm{MJ} / \mathrm{Nm}^{3}\right]$} & 18 & 18 \\
\hline
\end{tabular}

${ }^{1}$ Reduced to zero by electrical trace heating.

${ }^{2}$ Simulated by natural gas during the first phase of testing. 
The height of the lab-scale installation was limited by the height of the laboratory. The linear gas velocities in the lab-scale and pilot plant risers are comparable $( \pm 6 \mathrm{~m} / \mathrm{s})$, so the residence time of the gas in the lab-scale riser is relatively short. Most of the gas residence time takes place in the settling chamber. The estimated residence times of the gas in the settling chamber for the lab-scale and pilot plant (respectively 2 and 3 seconds) are comparable. The linear gas velocities in the fluidized bed combustor were increased from 0.2 to $0.5 \mathrm{~m} / \mathrm{s}$ to keep the installation small. The linear gas velocity in the pilot scale fluidized bed combustor is compared to conventional BFB combustors still low. Typical values for commercial scale BFB combustors are between 1 and $2 \mathrm{~m} / \mathrm{s}$.

Figure 6 shows a simplified process scheme of the integrated installation. The flue gas from the combustion section is cooled down to approximately $180^{\circ} \mathrm{C}$ before it is de-dusted in a bag-house filter. The heat is used to pre-heat the combustion air to $400^{\circ} \mathrm{C}$. Tar and dust from the OLGA gas cleaning will be used as fuel in the combustor in the future. For the moment this is simulated by adding natural gas to the combustor.

The producer gas leaving the MILENA reactor has to be cooled down to $400^{\circ} \mathrm{C}$ before it can enter the OLGA gas cleaning section. Cooling of producer gas containing tar is problematic. Tar will condense on cold surfaces and the sticky tar forms a layer to capture fine ash and char particles. These fine particles can form a porous layer with a very low thermal conductivity. This top layer can grow fast (e.g. $1 \mathrm{~mm} / \mathrm{h}$ ) and will decrease the cooler capacity and increase pressure drop over the cooler. The existence of the porous layer depends on the abrasive intensity of the gas flowing around the cooler surface. Approximately 1 $\mathrm{g} / \mathrm{Nm}^{3}$ of sufficiently large particles (at least $50 \mu \mathrm{m}$ ) can prevent the formation of this porous layer (van der Drift et al., 2004). The design of the used producer gas cooler is based on these principles. Cold spots on the cooler surface are prevented by applying co-current operation. The cooler surface is kept above $350^{\circ} \mathrm{C}$ to prevent condensation of tar. The formation of a porous layer is prevented by having some larger particles (lost bed material) in the producer gas. These larger particles are removed from the producer gas by a cyclone after the gas cooler. The fine dust particles (typically less than 5-10 $\mu \mathrm{m}$ ) are removed in the OLGA.

Tar is removed from the producer gas by the OLGA gas cleaning technology. The OLGA technology is based on scrubbing the producer gas with oil (Boerrigter et al., 2005). The tars are removed in two different stages (only one shown in Figure 6). In the first stage the producer gas is cooled and the condensed tars are collected. A bleed stream of the oil - tar mixture is sent to the combustor of the MILENA gasifier. In the second stage (absorber column) the light tars are removed from the producer gas. The scrubbing oil from the second stage is regenerated in a stripper. The stripper uses air to strip the light tars from the oil. The air containing light tars can be used as combustion air in the MILENA 
combustor. In the present system layout, the air is used as combustion air in the boiler. The temperature in the OLGA gas cleaning is kept above the dew point of the water in the gas (typically $74^{\circ} \mathrm{C}$ ) to prevent condensation of water.

The present pilot system includes downstream units to further clean the gas for final combustion in a boiler and meet the emission limits at ECN. Water, $\mathrm{NH}_{3}$ and low levels of $\mathrm{HCl}$ are removed from the producer gas in the wet scrubbing system called GASREIP (Verhoeff et al., 2007). GASREIP consists of three main columns (only one column is shown in Figure 6). In the first column the producer gas is quenched with cold water to condense out the water. In the second column $\mathrm{NH}_{3}$ is washed from the gas with cold water. The $\mathrm{NH}_{3}$ is stripped from the heated water by air in the third column. The water is cooled before it is sent to the second column again. The air containing $\mathrm{NH}_{3}$ can be used as combustion air in the MILENA combustor. In the present system layout the air is used as combustion air in the boiler. The cleaned dry producer gas is compressed to approximately 75 mbar. The pressurized gas had been used in a gas engine in the past. In the present system all the gas is sent to a boiler.

The previous burner and boiler were designed to combust low calorific gas produced by the gasification of chicken litter in the BIKVIN gasifier (Verhoeff et al., 2004). This configuration could not be re-used for the new MILENA system; the capacity of the boiler was too small. The original design capacity was 257 $\mathrm{kW}_{\text {th }}$ gas input, the MILENA pilot gasifier produces $620 \mathrm{~kW}$ of producer gas and therefore the boiler was replaced by a larger one. The previous design of the burner was not able to handle the increased combustion air flow; therefore the design of the old burner was adapted. 


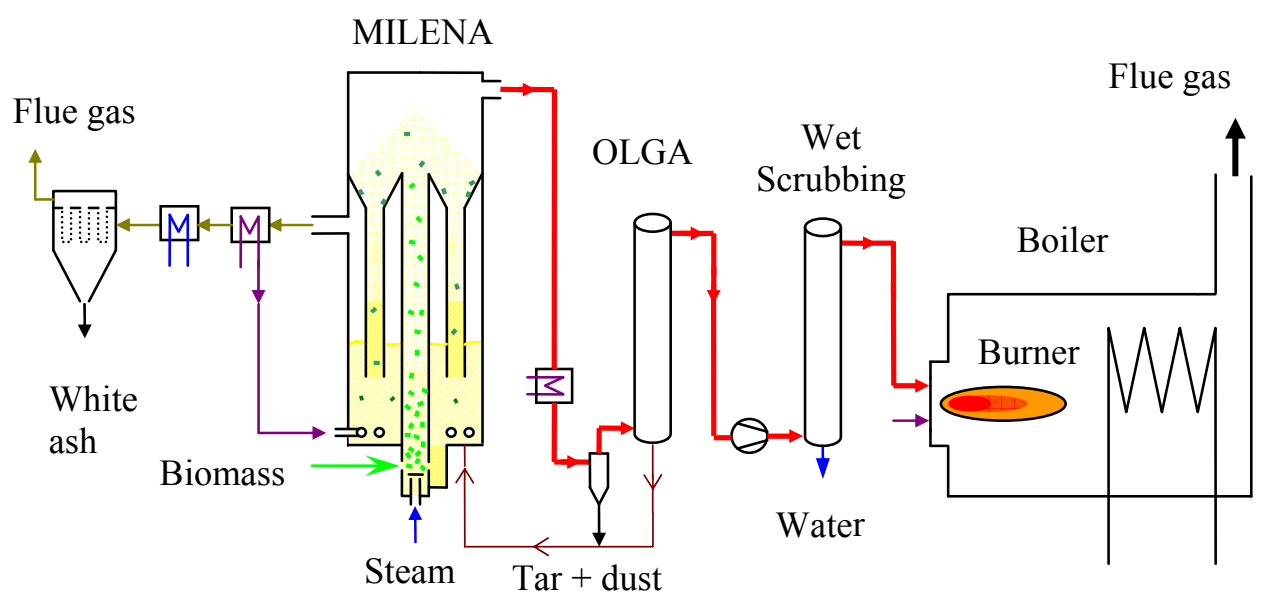

Figure 6. Simplified flow diagram of pilot-scale installation

\section{First results}

The first pilot plant tests were done in the summer of 2008 using sand as bed material. The installation was heated up during the night by combustion of natural gas in the fluidized bed. The test program had to be stopped, because of a mechanical failure inside the reactor, which caused a delay of several months in the test program. The test program was continued in 2009. The bed material was exchanged with olivine to lower the tar content.

Table 2 shows the composition of the wood used in the lab-scale and pilot scale installation. In the lab-scale installation wood particles of $0.7-2 \mathrm{~mm}$ were used. In the pilot plant white wood pellets with a diameter of $6 \mathrm{~mm}$ and an average length of $15 \mathrm{~mm}$ were used. 
Table 2. Compositions of used wood

\begin{tabular}{llcc}
\hline & & $\begin{array}{c}\text { Beech wood } \\
\text { chips }\end{array}$ & $\begin{array}{c}\text { Wood pellets } \\
\text { (white) }\end{array}$ \\
\hline $\mathrm{C}$ & [wt.\% d.a.f.] & 49.3 & 48.2 \\
$\mathrm{H}$ & [wt.\% d.a.f.] & 6.1 & 6.4 \\
$\mathrm{O}$ & [wt.\% d.a.f.] & 44.3 & 45.2 \\
$\mathrm{~N}$ & [wt.\% d.a.f.] & 0.193 & 0.130 \\
$\mathrm{~S}$ & [wt.\% d.a.f.] & 0.018 & 0.009 \\
$\mathrm{Cl}$ & [wt.\% d.a.f.] & 0.004 & 0.012 \\
$\mathrm{Ash}$ & [wt.\% d.b.] & 1.0 & 0.3 \\
$\mathrm{Water}$ & [wt.\% a.r.] & 10 & 9 \\
Volatiles & [wt.\% d.b.] & 83 & 82 \\
LHV & [kJ/kg d.a.f] & 18414 & 18536 \\
$\mathrm{HHV}$ & [kJ/kg d.a.f] & 19748 & 19929 \\
\hline
\end{tabular}

Table 3 shows the main measured gas composition for different bed materials for the lab-scale installation and the pilot plant for some selected tests. 
Table 3. Measured gas composition \& process data

\begin{tabular}{|c|c|c|c|c|c|c|}
\hline Installation & & $\mathrm{Lab}$ & $\mathrm{Lab}$ & $\mathrm{Lab}$ & Pilot & Pilot \\
\hline Bed material & & Sand & Sand & $\begin{array}{c}\text { Austrian } \\
\text { Olivine }\end{array}$ & Sand & $\begin{array}{c}\text { Austrian } \\
\text { Olivine }\end{array}$ \\
\hline Fuel flow & {$[\mathrm{kg} / \mathrm{h}]$} & 6.1 & 4.5 & 4.0 & 132 & 129 \\
\hline Steam & {$[\mathrm{kg} / \mathrm{h}]$} & 0.5 & 1.4 & 2.0 & 14 & \pm 20 \\
\hline Steam $/ \mathrm{BM}^{3}$ & {$[\mathrm{~kg} / \mathrm{kg}]$} & 0.1 & 0.3 & 0.5 & 0.1 & \pm 0.2 \\
\hline Combustion air & {$[\mathrm{kg} / \mathrm{h}]$} & 7.8 & 7 & 9.3 & 203 & 233 \\
\hline $\mathrm{CH}_{4}$ to combustor & {$[\mathrm{kg} / \mathrm{h}]$} & 0.2 & 0.1 & 0.2 & 6.5 & 1.1 \\
\hline Tcombustor ${ }^{4}$ & {$\left[{ }^{\circ} \mathrm{C}\right]$} & 903 & 902 & 922 & 917 & 902 \\
\hline Tgasifier $^{5}$ & {$\left[{ }^{\circ} \mathrm{C}\right]$} & 822 & 861 & 880 & 800 & 826 \\
\hline Gas yield $^{6}$ & {$\left[\mathrm{Nm}^{3} / \mathrm{kg}\right]$} & 0.8 & 0.8 & 1.0 & 0.8 & .9 \\
\hline $\mathrm{CO}$ & [vol\% dry] & 44.1 & 39.3 & 27.5 & 38.6 & 37.5 \\
\hline $\mathrm{H}_{2}$ & [vol\% dry] & 20.5 & 21.4 & 27.3 & 22.7 & 25.1 \\
\hline $\mathrm{CO}_{2}$ & [vol\% dry] & 10.4 & 13.9 & 24.8 & 12.2 & 15.0 \\
\hline $\mathrm{CH}_{4}$ & [vol\% dry] & 14.9 & 12.8 & 9.8 & 14.4 & 14.4 \\
\hline $\mathrm{C}_{2} \mathrm{H}_{\mathrm{y}}$ & [vol\% dry] & 5.6 & 5.1 & 3.8 & 5.1 & 5.4 \\
\hline $\mathrm{C}_{6} \mathrm{H}_{6}$ & [vol\% dry] & 1.4 & 1.2 & 1.0 & 1.2 & 1.0 \\
\hline $\mathrm{C}_{7} \mathrm{H}_{8}$ & [vol\% dry] & 0.15 & 0.13 & 0.09 & 0.24 & 0.10 \\
\hline $\mathrm{N}_{2}(+\mathrm{Ar})$ & [vol\% dry] & 2.4 & 6.0 & $3.4(+2)$ & 6.6 & 2.4 \\
\hline $\mathrm{H}_{2} \mathrm{~S}$ & [Vppm dry] & 57 & 70 & 92 & 76 & 86 \\
\hline COS & [Vppm dry] & 11 & $<10$ & $<10$ & $<10$ & $<10$ \\
\hline Tar & {$\left[\mathrm{g} / \mathrm{Nm}^{3}\right.$ wet $]$} & 41 & 32 & 18 & n.m. & 29 \\
\hline
\end{tabular}

The producer gas also contains several other pollutants which are not always measured. These pollutants are: Thiophenes $( \pm 15 \mathrm{Vppm}), \mathrm{HCN}( \pm 15$ $\mathrm{Vppm}), \mathrm{NH}_{3}( \pm 2000 \mathrm{Vppm})$ and $\mathrm{HCl}( \pm 30 \mathrm{Vppm})$. The measured tar concentrations are high compared to the FICFB process, because gasification takes place in a riser reactor at a low steam / biomass ratio. Typical values for the FICFB demonstration plant in Güssing process are $1-10 \mathrm{~g} / \mathrm{Nm}^{3}$ of tar at a steam biomass ratio between 0.7 and 1.1 (Hofbauer et al., 2002).

\footnotetext{
${ }^{3}$ The steam / biomass ratio is defined as the mass of steam added to the riser divided by the mass of biomass on an As Received basis.

${ }^{4}$ The combustor temperature is the average bed temperature in the fluidized bed combustor; the gasifier temperature is approximately $50-100^{\circ} \mathrm{C}$ lower.

${ }^{5}$ The gasifier temperature is inaccurate, because this is measured in the settling chamber. The temperature in the gasifier / riser is higher.

${ }^{6}$ The calculated gas yield is defined as the volume of dry gas divided by the mass of biomass on dry basis.
} 
The measured $\mathrm{N}_{2}$ concentration in the produces gas varies, the main reason is the variation in the amount of purging gas used to feed the fuel. The $\mathrm{N}_{2}$ concentration can be minimized by replacing nitrogen with $\mathrm{CO}_{2}$.

The During the pilot scale tests approximately $40 \mathrm{~kW}$ of natural gas was fed into the combustor bed to simulate the recycle of removed tar to the bed. The combustion air to the gasifier was heated by the flue gas cooler. No additional heat was sent to the pilot plant. The pilot scale gas composition is similar to the gas composition of the lab-scale experiment under similar process conditions. The amount of char available for combustion is according the calculated values based on the lab scale experiments. The basic processes in the pilot plant are similar to the lab-scale installation. The tests have not revealed any unexpected scale-up issues regarding the basic process.

The concentrations of $\mathrm{CO}$ and $\mathrm{C}_{\mathrm{x}} \mathrm{H}_{\mathrm{y}}$ in the flue gas have to be below the emission limits. To reduce these emissions from the combustor, secondary air is added to the freeboard.

Table 4 gives an indication of the emissions from the lab-scale installation and the pilot plant when clean wood is used as fuel. The emissions of CO strongly depend on the air to fuel ratio, the concentration rises sharply when the $\mathrm{O}_{2}$ content in the flue gas drops below 2 percent. The limits given in the first column are for the Netherlands, when waste (e.g. demolition wood) is used as a fuel.

Table 4. Measured flue gas emissions

\begin{tabular}{llccc}
\hline & & Limits & Lab-scale & Pilot plant \\
\hline Fuel & & Waste & Clean & Clean \\
& & wood & wood & wood \\
$\mathrm{O}_{2}$ & {$[\mathrm{vol} \%$ dry $]$} & 11 & 4.2 & 5 \\
$\mathrm{CO}_{2}$ & {$[\mathrm{vol} \%$ dry $]$} & - & 13.4 & 13 \\
$\mathrm{CO}$ & {$\left[\mathrm{mg} / \mathrm{Nm}^{3} @ 11 \mathrm{vol} \% \mathrm{O}_{2}\right.$ dry $]$} & 50 & \pm 30 & $<10$ \\
$\mathrm{NO}_{\mathrm{x}}$ & {$\left[\mathrm{mg} / \mathrm{Nm}^{3} @ 11 \mathrm{vol} \% \mathrm{O}_{2}\right.$ dry $]$} & 70 & \pm 120 & \pm 70 \\
\hline
\end{tabular}

The $\mathrm{CO}$ concentration in the flue gas coming from the pilot plant is in general lower than in the gas from the lab-scale installation. In both installations a relatively small amount of natural gas $( \pm 5 \%$ of thermal input) is fired in the fluidized bed combustor to simulate the recycle of removed tar. In the lab-scale installation, a clear increase in unburned concentrations $\left(\mathrm{CO}\right.$ and $\left.\mathrm{C}_{\mathrm{x}} \mathrm{H}_{\mathrm{y}}\right)$ can be seen when natural gas is fired. This can be attributed to the fact that the natural gas is fed at a position near the wall and apparently is not mixed well in the bed. In the pilot plant the natural gas is fed through nozzles in the bed, this reduces $\mathrm{CO}$ and $\mathrm{C}_{\mathrm{x}} \mathrm{H}_{\mathrm{y}}$ emissions. The $\mathrm{NO}_{\mathrm{x}}$ emission of the lab-scale installations is above the limit for waste wood. The $\mathrm{NO}_{\mathrm{x}}$ emission is close to the limit. Further testing will 
focus on reduction of the $\mathrm{NO}_{\mathrm{x}}$ emissions. A possible option for $\mathrm{NO}_{\mathrm{x}}$ reduction is the SNCR process (Selective Non-Catalytic Reduction), where $\mathrm{NH}_{3}$ is injected in the freeboard of the installation to react with $\mathrm{NO}_{\mathrm{x}} \cdot \mathrm{NH}_{3}$ is present in the producer gas from the gasifier section and is dissolved in water by using a wet scrubber. The $\mathrm{NH}_{3}$ is stripped from the water by air. This air / $\mathrm{NH}_{3}$ mixture can be used for the SNCR process.

One of the major operational problems in fluidized bed combustors and gasifiers is agglomeration of the bed material. Tests in the lab-scale and pilot scale MILENA, using clean wood as fuel, have not resulted in agglomeration of the bed material so far. Further tests with demolition wood as fuel are planned to test if agglomeration can also be prevented with these more 'difficult' fuels. A typical measure to reduce the risk of bed agglomeration is the removal of used bed material and addition of fresh bed material, but the replacement ratio has be kept to a minimum for economical reasons.

\section{Further development}

Lab-scale MILENA SNG research continues and is focused on long duration testing of the different methanation and gas pre-treatment catalysts. The existing pilot plant OLGA will be connected to the MILENA gasifier. Tests of the integrated system are planned for 2009. When these tests are positive a $10 \mathrm{MW}$ MILENA - OLGA - gas engine demonstration will be build. This demonstration will be taken in operation in 2012 and will be followed by a large (50 MW) SNG demonstration.

For further scale up a small increase in pressure is foreseen (between 1 and 5 bar). System studies done by ECN have shown that a small increase in pressure is beneficial for overall efficiency from wood to SNG.

\section{Conclusions}

First results from the MILENA pilot plant are promising; the gas composition is similar to the composition of the gas from the lab-scale plant and according to expectations. The flue gas emissions are comparable to the emissions from the lab-scale unit, which is an indication of stable operation. The temperatures in the fluidized bed combustor are according design; which means that the conversion of the fuel is as expected (near 100\%).

Mechanical failure of part of the installation has caused a significant delay in the test program. The causes for the mechanical failure are identified and a new design for some of the internals is made. Extensive testing has to prove if the mechanical problems are solved. 
The adapted burner was able to ignite and combust the producer gas from the MILENA pilot gasifier. The capacity of the boiler was sufficient. Extensive flue gas measurements are required to check if this burner design can meet the local emission limits.

Preparations for a $10 \mathrm{MW}$ demonstration are underway. If the MILENA pilot installation operates well the demonstration installation is expected to be taken into operation in 2012.

\section{References}

Boerrigter, H., van Paasen, S. B. V., Bergman, P. C. A., Könemann, J.-W., and Emmen, R., "Tar removal from biomass product gas; development and optimisation of the OLGA tar removal technology", 14th European Biomass Conference \& Exhibition, 17-21 October 2005, Paris, France, 2005.

Hofbauer, H., Veronik, G., Fleck, T., Ruach, R., Mackinger, H., and Fercher, E., "The FICFB - Gasification Process", 1997.

Hofbauer, H.; Rauch, R.; Loeffler, G.; Kaiser, S; Fercher, E. \& Tremmel, H.,"Six years experience with the FICFB-Gasification process", 12th European Conference on Biomass for Energy, Industry and Climate Protection, 17-21 June 2002, Amsterdam, The Netherlands, 2002.

Kanaar, M. and van Dongen, A., "Co-gasification at the Buggenum IGCC Power Plant", DGMK-Fachtagung "Energetische Nutzung von Biomassen", 24. bis 26. April 2006 in Velen (Deutschland), 2006.

Mozaffarian, H., Zwart, R. W. R., Boerrigter, H., Deurwaarder, E., and Kersten, S. R. A., "Green gas as SNG (synthetic natural gas); a renewable fuel with conventional quality", Science in thermal and chemical conversion, 30 August - 2 September 2004, Vancouver, Canada; also available at www.ecn.nl as report ECN-RX-04-085, 2004.

Paisley, M. A. and Overend, R. P., "Verification of the Performance of Future Energy Resources' SilvaGas ${ }^{\circledR}$ Biomass Gasifier -- Operating Experience in the Vermont Gasifier", Pittsburg Coal Conference, 2003, 2002.

Proell, T., Rauch, R., Aichernig, C., and Hofbauer, H., "Fluidized bed steam gasification of solid biomass - Performance characteristics of an 8 MWth combined heat and power plant"International Journal of Chemical Reactor Engineering, October 2007. 
van der Drift, A. and Pels, J. R., "Product gas cooling and ash removal in biomass gasification", ECN, Petten, The Netherlands; also available at www.ecn.nl as report ECN-C--04-077, 2004.

van der Drift, A., van der Meijden, C. M., and Strating-Ytsma, S. D., "Ways to increase the carbon conversion of a CFB-gasifier", The 12th European Conference on Biomass for Energy, 17-21 June 2002, Amsterdam, the Netherlands; also available at www.ecn.nl as report ECN-RX-02-014, 2002.

van der Meijden, C. M., van der Drift, A., and Vreugdenhil, B. J., "Experimental results from the allothermal biomass gasifier Milena", 15th European Biomass Conference \& Exhibition, 7-11 May 2007, Berlin, Germany; also available at www.milenatechnology.com, May 2007.

Verhoeff, F., Paasen, S. V. B., Rabou, L. P. L. M., Emmen, R., Buwalda, R. A., and Klein Teeselink, H., "700 hours duration test with integral $500 \mathrm{~kW}$ biomass gasification system", 15th European Biomass Conference, 7-11 May 2007, Berlin, Germany, 2007.

Verhoeff, F., van der Meijden, C. M., Ratering, H., Kant, H. F., and Bos, H., "Branderonderzoek ten behoeve van de verbranding van laag calorisch ammoniakrijk biomassa stookgas", ECN, Petten, the Netherlands; also available at www.ecn.nl as report ECN-C--04-104, Petten, October 2004.

Waldheim, L., "Status of Chrisgas project; production of hydrogen-rich synthesis gas", Synbios, the syngas route to automotive biofuels, conference held from 1820 May 2005, Stockholm, Sweden, 2005. 